\title{
ALTERNATIF PENILAIAN EVALUASI PEMBELAJARAN PASCA PANDEMI COVID - 19 PADA JENJANG PENDIDIKAN SEKOLAH DASAR
}

\author{
Eka Diah Febrianti ${ }^{1}$, Isdania ${ }^{2}$, Nadya Putri ${ }^{3}$, Sasi Maghfiroh ${ }^{4}$ \\ Jurusan Administrasi Pendidikan \\ Fakultas Ilmu Administrasi \\ Universitas Brawijaya \\ Jl. Veteran, Ketawanggede Kecamatan Lowokwaru, Kota Malang, Jawa Timur
}

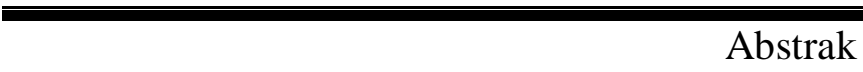

strak

Pendidikan merupakan usaha yang dilakukan secara sadar serta terencana guna menciptakan suasana belajar dan proses pembelajaran yang secara aktif mampu membuat peserta didik mengembangkan potensi yang dimiliki. Pendidikan diharapkqn mampu menciptakan peserta didik yang memiliki kekuatan spiritual keagamaan, pengendalian diri, kepribadian, kecerdasan, serta akhlak mulia. Keterampilan tersebut tidak hanya diperlukan bagi dirinya sendiri, akan tetapi jugs berguna bagi masyarakat bangsa dan negara. Upaya yang dapat dilakukan untuk memastikan apakah suatu tujuan pendidikan telah tercapai yaitu dengan melalukan evaluasi. Evaluasi ini dilakukan guna menentulan apalah suatu program telah layak. Selain itu, evaluasi dimaksudkan untuk mengendalikan, menjamin, dan menetapkan mutu pendidikan terkait dengan berbagi kompenen pendidikan. Evaluasi dilakukan pada semua jenjang dan jenis pendidikan dalam rangka mempertanggung jawabkan kepada peserta didik terkait dengan penyelenggaran pendidikan yang telah dilakukan oleh suatu lembaga pendidikan. Dengan demikian maka antara kegiatan belajar mengajar dan evaluasi merupakan suatu rangkaian yang berkesinambungan dan tidak dapat dipisahkan. Hal ini dikarenakan evaluasi digunakan sebagai alat ukur yang berguna untuk mengetahui dan menentukan tingkat keberhasilan peserta didik dalam kegiatan belajar.

Kata kunci : Evaluasi, Penilaian, Alternatif Penilaian

\section{Abstrac}

Education is a conscious and planned effort to create a learning atmosphere and learning process that is actively able to make students develop their potential. Education is expected to be able to create students who have religious spiritual strength, self-control, personality, intelligence, and noble character. These skills are not only needed for themselves, but also useful for the people of the nation and state. Efforts that can be made to ascertain whether an educational goal has been achieved is by conducting an evaluation. This evaluation is carried out to determine whether a program is feasible. In addition, evaluation is intended to control, guarantee, and determine the quality of education related to the sharing of educational components. Evaluation is carried out at all levels and types of education in order to be 
accountable to students related to the implementation of education that has been carried out by an educational institution. Thus, between teaching and learning activities and evaluation is a continuous series and cannot be separated. This is because evaluation is used as a useful measuring tool to determine and determine the level of success of students in learning activities.

Keywords : Evaluation, Assessment, Alternative Assessment

\section{PENDAHULUAN}

Awal tahun 2020 merupakan awal dimana pandemi covid-19 dimulai, tak hanya di Indonesia saja tetapi di seluruh bagian dunia juga sedang mengalami wabah yang sangat mengkhawatirkan masyarakat. Di Indonesia sendiri awal pandemi covid dimulai pada bulan maret 2020 yang mengharuskan segala aktivitas dan fasilitas publik harus ditutup karena dapat membantu penyebaran wabah ini semakin cepat. Di Beberapa negara pandemi ini sangat cepat menular melalui kerumunan orang sehingga kasus covid di tiap negara menjadi meningkat dengan cepat dikarenakan masih banyak kerumunan masyarakat. Untuk membatasi penyebaran penyakit ini, pemerintah mengeluarkan sebuah kebijakan yang mengharuskan masyarakat untuk melakukan segala macam aktivitas apapun di rumah atau disebut dengan Social Distancing, dan Physical

Distancing (Mahmudah et al., 2021).

Dengan adanya kebijakan baru tersebut, menyebabkan beberapa bidang di pemerintahan harus mengalami dampaknya termasuk dalam bidang pendidikan. Munculnya wabah ini mengharuskan seluruh sekolah ditutup secara total dan semua kegiatan pembelajaran dilakukan dirumah atau disebut dengan istilah BDR (Belajar Dari Rumah) atau juga disebut dengan Pembelajaran Dalam Jaringan (Daring). Pembelajaran daring pada masa pandemi merupakan hal baru bagi pendidik dan peserta didik dimana mereka harus menggunakan bantuan teknologi (zoom, meet, google classroom, dsb) untuk membantu proses pembelajaran dan hal tersebut menyulitkan beberapa pendidik karena masih banyak pendidik di Indonesia gaptek. Tak hanya proses pembelajaran saja yang terganggu, dari segi pelaksanaan evaluasi peserta didik juga mengalami hambatan dimana pendidik harus memikirkan cara yang paling efektif guna melakukan evaluasi pembelajaran.

Namun, pandemi covid-19 pada saat ini sudah berangsur-angsur membaik dan dapat diatasi oleh pemerintah. Menjelang 
akhir tahun 2021 hampir diseluruh dunia telah mampu mengatasi pandemi covid-19 sehingga segala kegiatan dan aktivitas sudah mulai pulih kembali. Di Indonesia sendiri beberapa kegiatan di berbagai lembaga telah dimulai kembali dan untuk fasilitas publik juga sudah dioperasikan kembali. Meskipun telah mengadakan kegiatan dan membuka fasilitas publik, protokol kesehatan covid masih diberlakukan untuk mencegah terjadinya penularan secara massal.

Seperti di aspek pendidikan, beberapa sekolah di jenjang SD-SMA sudah mulai sekolah secara tatap muka. Pemerintah Indonesia hanya mengizinkan tatap muka secara offline di sekolah dengan syarat daerah tersebut kasus covid-19 sudah menurun dan tergolong daerah yang sudah melakukan vaksin sebesar $80 \%$. Untuk mempersiapkan sekolah offline maka pendidik beserta staf kependidikan sudah mulai merancang terkait perencanaan pembelajaran hingga sampai pada metode evaluasi penilaian pembelajaran.

Menurut Arikunto dan Jabar, 2004, menegaskan bahwa penilaian pembelajaran merupakan hal penting yang harus dilakukan oleh pendidik guna mengevaluasi apa saja kelebihan dan kekurangan dari pembelajaran tersebut serta mengetahui pemahaman peserta didik terkait pembelajaran tersebut yang akhirnya memunculkan alternatif dalam pengambilan keputusan terkait metode pembelajaran. sedangkan menurut Akhmad Sudrajat mendefinisikan penilaian merupakan sebuah cara dan penggunaan beberapa metode penilaian yang memiliki tujuan untuk mendapatkan informasi yang berkaitan dengan ketercapaian hasil belajar peserta didik

Dengan adanya kebijakan mengenai sekolah offline maka pendidik akan membuat alat pengukuran untuk mengevaluasi peserta didiknya pada tahun ajaran baru di semua jenjang pendidikan. pada tingkat sekolah dasar biasanya guru melakukan evaluasi dengan menganalisis kemampuan peserta didik dalam menangkap materi pembelajaran, kemampuan untuk mengingat, kemampuan membuat imajinasi dan kemampuan lainnya yang dimana kemampuan tersebut akan berguna untuk menunjang pada jenjang berikutnya. Dalam hal ini pendidik juga dapat mengkombinasikan penilaian selama pembelajaran daring dan pembelajaran luring sehingga penggabungan dua metode tersebut akan memberikan banyak dampak positif bagi sekolah, pendidik dan peserta didik.

Berdasarkan pemaparan diatas maka permasalahan yang terkait dengan evaluasi ini adalah bagaimana pendidik membuat 
alternatif pembelajaran yang efektif dan efisien serta menguntungkan semua pihak.

\section{METODE}

Penelitian ini menggunakan metode library research (studi kepustakaan) dimana studi ini merupakan penelitian yang berfokus pada studi literatur yang terdiri dari buku, catatan, atau laporan dari hasil penelitian terdahulu. Teknik pengumpulan yang dilakukan dalam penelitian ini adalah menganalisis jurnal penelitian, artikel ilmiah, buku dan sebagainya yang berhubungan dengan tema penelitian. Kemudian data yang telah terkumpul akan dianalisis kembali agar dapat menemukan alternatif evaluasi pembelajaran setelah pasca pandemi pada jenjang sekolah dasar.

\section{HASIL DAN PEMBAHASAN}

\section{1) Definisi Evalusi Penilaian}

Evaluasi sebagai bagian dari proses pembelajaran. Evaluasi dan proses pembelajara tidak dapat dipisahan dari kegiatan mengajar karena merupakan serangkaian proses yang berkesinambungan. Dalam kegiatan pendidikan, evaluasi memiliki arti yang sangat penting. Dengan dilakukannya evaluasi maka akan diketahui sejauh mana tingkat kerberhasilan yang sudah dicapai siswa atas bahan ajar yang telah disampaikan pendidik. Dengan demikian maka evaluasi yang dilakukan akan mampu mengetahui secara akurat serta meyakinkan tujuan dari pembelajaran. Kegiatan evaluasi perlu diptimalkan mengingat betapa pentingnya faktor input,proses ,dan output guna menciptakan efektivitas dari suatu pembelajaran yang mana hal ini kemudian digunakan sebagai pertimbangan dalam menentukan keberhasilan proses belajar dari peserta didik.

Menurut NSW department of education tentang penilaian, mendeskripsikan bahwa penilaian merupakan suatu kumpulan dari hasil dan realita yang terjadi untuk dibuat sebuah keputusan yang selanjutnya berguna bagi masa depan peserta didik. Sedangkan seperti yang dikutip dalam Peraturan Pemerintah No 19 tahun 2005 bab 1 pasal 1 ayat 17 , penilaian diartikan sebagai suatu usaha sadar yang dilakukan oleh pendidik untuk memberikan informasi terkait dalam pencapaian peserta didik guna mengukur keberhasilan dalam proses belajar mengajar.

Jadi dapat disimpulkan bahwa evaluasi penilaian adalah salah satu instrumen penting dalam pendidikan yang mencakup tentang proses pengumpulan data yang komprehensif dan dapat menggambarkan perkembangan peserta didik sehingga memberikan informasi yang lengkap mengenai hasil belajar siswa dan menentukan keputusan untuk tahap selanjutnya. 


\section{2) Tujuan Penilaian Pembelajaran}

Dalam penilaian terdapat beberapa tujuan yang mana menjadi sebuah navigasi bagi penilaian. Seperti yang disebutkan oleh Nana Sudjana (1995:4), tujuan penilaian adalah sebagai berikut:

a. Penilaian digunakan sebagai alat untuk mendeskripsikan tentang kecakapan belajar peserta didik yang mana hal ini digunakan untuk mengidentifikasi kelebihan dan kekurangan yang terjadi dalam setiap mata pelajaran dalam kegiatan belajar mengajar.

b. Penilaian digunakan untuk memantau sejauh mana keberhasilan yang dicapai dalam proses pengajaran di suatu instansi sekolah dengan melihat tingkat keefektifan sekolah yang bisa merubah tingkah laku peserta didik sehingga sejalan dengan tujuan pendidikan.

c. Penilaian memiliki tujuan untuk sebagai bahan evaluasi bagi suatu sekolah untuk melihat apakah membutuhkan perbaikan dalam berbagai segi seperti program pendidikan dan pengajaran dan juga strategi pelaksanaannya.

d. Penilaian digunakan untuk bahan pertanggungjawaban yang bersumber dari pihak sekolah kepada pihak-pihak yang berkepentingan seperti pihak pemerintah, masyarakat dan jua orang tua peserta didik.

\section{3) Prinsip Penilaian Pembelajaran}

Penilaian pembelajaran merupakan hal yang menjadi sangat kompleks dan paling inti dalam kegiatan belajar mengajar dimana hal ini dapat digunakan sebagai bahan untuk menjaga kualitas dan mutu peserta didik dalam rangka pencapaian tujuan pendidikan. Menurut Helmawati (2019:214-215), prinsip penilaian dikemukakan sebagai berikut :

a. Sahih, yang dimaksud dalam prinsip ini adalah penilaian harus berdasarkan dengan data yang merefleksikan kemampuan peserta didik yang sedang diukur.

b. Objektif, prinsip ini merupakan prinsip yang menyatakan bahwa penilaian tidak boleh berdasarkan dengan subjektivitas penilai tetapi harus berdasarkan dengan realita dan juga dengan penerapan prosedur dan juga kriteria yang jelas.

c. Adil, prinsip ini memiliki suatu artian bahwa penilaian dilakukan dengan tanpa melihat latar belakang dari seorang peserta didik yang dinilai. Penilaian ini dilakukan tanpa memandang suku, ras, agama, budaya, status sosial ekonomi dan juga gender.

d. Terpadu, prinsip ini memiliki artian bahwa prosedur penilaian 
merupakan suatu langkah yang tidak boleh terlewatkan dalam kegiatan belajar mengajar yang ada suatu instansi sekolah.

e. Holistik dan berkesinambungan, prinsip ini memiliki artian bahwa penilaian yang dilakukan oleh tenaga pendidikan harus meliputi seluruh aspek kompetensi yang ada dengan menggunakan teknik yang sesuai dengan kompetensi yang dikuasai oleh peserta didik.

f. Sistematis, prinsip ini memiliki artian bahwa penilaian harus dilakukan dengan berdasar sesuai rencana dan juga sesuai dengan langkah-langkah yang telah ditentukan.

g. Berdasarkan kriteria, prinsip ini memiliki artian bahwa penilaian harus berpegang kepada kriteria yang telah ditentukan.

h. Akuntabel, prinsip ini memiliki artian bahwa penilaian ini dapat dipertanggungjawabkan

kebenarannya.

\section{4) Bentuk-bentuk Penilaian Evaluasi}

\section{Pembelajaran}

Menurut Permendikbud No. 23 Tahun 2016 penilaian merupakan sebuah proses pengumpulan serta pengolahan data seperti informasi tujuannya yaitu untuk mengukur pencapaian hasil belajar peserta didik.
Penilaian ini pada umumnya sering dilakukan oleh tenaga pendidik seperti guru tujuannya untuk mengetahui seberapa besar pencapaian hasil belajar siswa. Penilaian ini dilakukan bukan hanya untuk mengukur pencapaian hasil belajar siswa saja akan tetapi untuk meningkatkan kemampuan dari peserta didik itu sendiri. Jika peserta didik mengetahui hasil penilaian dari proses pembelajaran yang selama ini dilakukan maka akan lebih termotivasi lagi untuk meningkatkan semangat belajarnya. Maka dari itu proses dari penilaian ini dibutuhkan data dan informasi yang valid, lengkap dan akurat agar guru bisa mengambil keputusan yang tepat untuk penilaian peserta didiknya. Berikut ini merupakan bentuk-bentuk dari evaluasi pembelajaran secara manual yang sering dilakukan oleh guru terhadap peserta didik pada jenjang Sekolah Dasar:

\section{a. Evaluasi Pembelajaran Produk}

Bentuk evaluasi pembelajaran produk lebih menekankan pada hasil dan proses. Evaluasi pembelajaran produk ini dalam penilaiannya lebih melihat kemampuan dari peserta didik yang membuat suatu produk atau seni. Biasanya dalam jenjang Sekolah Dasar guru lebih memberikan tugas berupa karya seni yang dimana dalam prosesnya harus melibatkan keterampilan dari peserta didik. Dalam jenjang SD guru biasanya memberikan tugas berupa menggambar di 
buku gambar atau di kanvas, merajut, serta membuat hiasan bunga. Dalam penilaian pembelajaran produk ini dilakukan dengan 2 cara yaitu penilaian hasil dan penilaian proses. Penilaian hasil berupa hasil akhir dari tugas yang diberikan guru seperti gambar,lukisan, hiasan bunga. Sedangkan penilaian proses biasanya guru lebih melihat ke teknik menggambarnya dan peralatan yang digunakan.

\section{b. Evaluasi Portofolio}

Penilaian evaluasi portofolio merupakan penilaian yang dilakukan melalui koleksi hasil karya dari peserta didik. Biasanya penilaian ini dilakukan oleh guru secara sistematis mulai dari pengumpulan tugas-tugas peserta didik yang kemudian nantinya tugas-tugas peserta didik tersebut dinilai. Disini guru melakukan penilaian secara terus menerus karena sebagai refleksi perkembangan berbagai kompetensi peserta didik. Selain itu juga untuk mengukur tingkat perkembangan kemajuan siswa. Dalam jenjang Sekolah Dasar penilaian portofolio ini sering dilakukan oleh guru karena guru lebih efektif memberikan ujian berbasis paper untuk peserta didiknya yang kemudian nantinya ujian tersebut di kumpulkan ke guru kemudian di nilai.

\section{c. Evaluasi Unjuk Kerja/Performance}

Bentuk penilaian evaluasi unjuk kerja/performance ini merupakan bentuk penilaian yang dilakukan oleh guru dengan cara melihat langsung atau melakukan pengamatan peserta didik secara langsung di kelas pada saat pembelajaran. Jadi penilaian ini lebih memperhatikan bagaimana aktivitas siswa di kelas seperti tingkah laku, interaksi, dan sikap dari peserta didik. Adapun bentuk dari penilaian unjuk kerja/performance ini seperti lisan, keterampilan bicara, berpidato, membaca puisi, berdiskusi, olahraga, dan partisipasi dalam diskusi. Dalam jenjang Sekolah Dasar penilaian berdasarkan performance ini lebih cenderung sering dilakukan oleh guru terhadap peserta didiknya. Biasanya guru cenderung memberikan tugas seperti membuat pidato atau puisi dan kemudian nantinya akan dibaca oleh masing-masing peserta didik di depan kelas. Dari sinilah guru bisa melakukan penilaian pengamatan secara langsung pada saat peserta didik sedang membaca puisi atau berpidato di depan kelas. Selain itu guru juga biasanya melakukan penilaian kepada peserta didik pada saat guru sedang menjelaskan materi di kelas. Namun di sela-sela penjelasan guru menyelipkan pertanyaan yang nantinya akan dijawab oleh peserta didik. Dari situ juga guru bisa melakukan penilaian seberapa aktif peserta didiknya dalam menerima pelajaran. 


\section{d. Evaluasi Tertulis}

Penilaian evaluasi tertulis inilah yang paling umum dilakukan oleh guru bahkan semua sekolah yang ada di Indonesia juga menggunakan penilaian tertulis untuk mengukur tingkat keberhasilan siswa. Biasanya penilaian tertulis ini dilaksanakan pada akhir pertengahan semester atau di akhir semester pembelajaran. Adapun fungsi dari penilaian evaluasi tertulis ini yaitu untuk mensuplai jawaban dan memilih jawaban. Jadi peserta didik nantinya diberi soal, dimana soal tersebut berisi pilihan ganda beserta melengkapi jawaban essay. Dari situlah nantinya guru bisa melakukan penilaian dari jawaban yang sudah dikerjakan oleh peserta didik.

Dari keempat penilaian evaluasi pembelajaran diatas merupakan penilaian yang sering dilakukan pada jenjang Sekolah Dasar saat ini. Namun pada tahun 2019 masuknya wabah Pandemi Covid 19 ke Indonesia membawa perubahan dalam segala bidang terutama bidang pendidikan. Dari adanya pandemi covid 19 ini membuat pemerintah menetapkan kebijakan baru yakni merubah sistem persekolahan yang semula tatap muka menjadi online. Pembelajaran online atau daring merupakan suatu model pembelajaran terbaru baru-baru ini yang diterapkan sejak pandemi covid 19. Pembelajaran daring merupakan pembelajaran yang pelaksanaannya menggunakan media elektronik sebagai penunjang pembelajaran seperti laptop, hp, komputer. Walaupun sedang terjadi pandemi covid 19, pendidikan dan pembelajaran harus tetap dilaksanakan sebagai upaya untuk membantu peserta didik meningkatkan potensinya tanpa melihat suatu keadaan yang sedang terjadi saat ini. Jadi pandemi covid 19 bukan jadi penghalang peserta didik untuk terus belajar. Berbicara mengenai pembelajaran secara daring tentunya penilaian yang dilakukan oleh guru juga melalui online. Penilaian evaluasi pembelajaran sangat penting dilakukan agar guru bisa melihat dan mengukur kemampuan peserta didiknya, selain itu guru juga bisa mengukur kelemahan dan kelebihan saat melakukan pembelajaran.

\section{5) Penilaian Pembelajaran Pada Saat Pandemi Covid 19}

Adapun penilaian evaluasi pembelajaran yang dilakukan oleh guru pada jenjang Sekolah Dasar pada masa pandemic covid 19 ini diantaranya:

\section{a. Penilaian Secara Online}

Penilaian pada masa pandemic covid 19 ini dilakukan secara online. Dalam melakukan penilaian secara online membuat guru tidak bisa langsung mengetahui kemampuan peserta didik dalam menerima materi yang diajarkan. 
Jadi semua guru disini harus merubah strategi penilaian yang semula offline menjadi online. Disini guru bisa memberikan tugas kepada peserta didik seperti tugas video ataupun tugas portofolio yang nantinya setelah dikerjakan harus dikirim melalui grup WhatsApp. Dengan metode seperti itu guru tetap bisa melakukan penilaian evaluasi pembelajaran kepada peserta didiknya walaupun secara online.

\section{b. Penilaian Berdasarkan Tugas Harian yang Dikerjakan}

Pada saat pembelajaran daring disini guru juga bisa memberikan tugas-tugas harian atau mingguan kepada peserta didik. Hal ini merupakan salah satu dari strategi guru untuk melakukan penilaian evaluasi pembelajaran secara daring, dimana guru melakukan penilaian disini dilihat dari keefektifan dan kedisiplinan dalam mengumpulkan tugas. Untuk peserta didik yang rajin dan benar menjawab soal-soal yang diberikan oleh guru maka hal ini menjadi sesuatu yang penting untuk dipertimbangkan guru dalam memberikan nilai kepada peserta didik.

\section{c. Penilaian Berdasarkan Kehadiran Peserta Didik Saat Pembelajaran Daring}

Penilaian berdasarkan kehadiran peserta didik ini juga merupakan penentu guru dalam melakukan penilaian. Pada pandemic covid 19 ini semua guru telah merubah strategi dalam menentukan penilaian untuk peserta didiknya. Salah satu strategi lain yaitu dilihat dari kehadiran peserta didik di zoom ataupun grup whatsapp. Disini guru bisa menugaskan kepada peserta didik untuk melakukan absen dengan cara berfoto lengkap dengan menggunakan seragam sesuai dengan hari kemudian foto tersebut dikirim melalui grup whatsapp serta diberi nama. Dari kehadiran peserta didik di zoom maupun di grup whatsapp bisa dijadikan penentu guru dalam melakukan penilaian evaluasi pembelajaran.

\section{d. Merujuk Kepada Nilai Rapor \\ Semester Sebelum Covid 19}

Strategi penilaian evaluasi pembelajaran yang dilakukan oleh guru selanjutnya yaitu mengacu pada nilai rapor siswa sebelum pandemic covid 19. Hal ini dilakukan oleh guru karena guru tidak bisa melihat secara langsung kemampuan peserta didiknya sehingga membuat guru tidak bisa mengenal karakter masingmasing peserta didiknya secara langsung. Untuk itu guru memberikan penilaian baik secara online selain itu juga mengacu pada rapor sebelum pandemic covid 19. Dengan begitu, guru bisa memberikan penilaian evaluasi pembelajaran kepada peserta didiknya dengan cara memperkirakan nilai 
yang akan diberikan dengan berpatokan pada nilai sebelum pandemic covid 19 .

Walaupun pembelajaran dilaksanakan secara online, dari keempat strategi penilaian evaluasi pembelajaran pada peserta didik di masa pandemic covid 19 sudah terlihat bahwa penilaian yang sudah dilakukan guru menggambarkan kemampuan dari masing-masing peserta didik. Untuk itu diharapkan guru untuk selalu meningkatkan kemampuannya dalam melaksanakan proses pembelajaran. Khususnya di masa pandemic covid 19 ini guru harus lebih meningkatkan kemampuan untuk mengajar peserta didik agar lebih efektif lagi dengan begitu proses penilaian evaluasi pembelajaran dapat terus dilakukan secara objektif yang merupakan suatu gambaran otentik dari kemampuan peserta didik.

\section{6) Rekomendasi Penilaian}

\section{Pembelajaran Pasca Pandemi Covid}

$\underline{19}$

Berdasarkan hasil dari penelitian mengenai evaluasi pembelajaran pada jenjang sekolah dasar, maka ada beberapa alternatif penilaian yang dapat digunakan sebagai metode baru dalam evaluasi penilaian pada jenjang sekolah dasar oleh karena itu sesuai dengan pendapat dari Thomas R Guskey dalam Assessment and Grading in the Midst of a Pandemic (Ed
Week, 13 April 2020), menyatakan, dalam masa pandemi ini, penilaian sebaiknya menitik beratkan pada umpan balik/feedback daripada skor/ grading.

Penilaian sebaiknya difokuskan pada penilaian formatif, yaitu bagaimana membantu siswa memahami konsep dan materi dengan baik dan benar sehingga mereka mampu mencapai tujuan pembelajaran yang ditetapkan. Contohnya di negara Philippine, biasanya guru memberikan Live examination bagi muridmuridnya, adapun materi yang digunakan adalah materi pertemuan sebelumnya, dari hal tersebut seorang guru memberikan penilaian secara langsung terhadap jawaban muridnya, sehingga hal tersebut adanya kesesuaian antara kemampuan murid dalam memahami materi dengan nilai yang didapatkan murid tersebut. Dan untuk tahap akhir seorang guru merekapitulasi seluruh nilai dari awal sampai pertemuan akhir dan dapat diputuskan apakah murid tersebut berhasil dalam pembelajaran nya atau tidak, yang kemudian hasil tersebut dilaporkan kepada siswa, orang tua maupun pihak sekolah. Dari hal tersebut maka diharapkan adanya transformasi penilaian untuk pembelajaran pasca pandemi.

Alternative penilaian lainnya yaitu dalam hal mengelola dan melaporkan hasil evaluasi pembelajaran peserta didik ini bisa memanfaatkan kecanggihan teknologi yang 
ada, apalagi di jaman society 5.0, dimana semua hal berjalan dengan berlandaskan teknologi. Dalam pendidikan sendiri teknologi bisa diaplikasikan dalam hal pengolahan dan juga pelaporan atas evaluasi peserta didik. Seperti pada sebelumnya pengelolaan penilaian ini dilakukan secara digital seperti pada Microsoft Excel tetapi bentuk pelaporan evaluasi ini masih berbentuk hard file dalam buku atau yang biasa disebut raport. Demi menunjang keoptimalan dan juga upgrade sistem pendidikan yang lebih modern dan digital. Maka rekomendasi atau alternative pelaporan ini bisa dengan menggunakan website yang dapat diakses oleh guru, peserta didik dan juga orang tua peserta didik.

Raport digital atau E-Raport ini bisa digunakan sebagai tempat untuk mengambil data-data penting seperti data kesiswaan, nilai-nilai hasil evaluasi pembelajaran sampai pada tagihan terkait biaya pendidikan. Dan juga terdapat opsi untuk mencetak hasil evaluasi peserta didik. E-Raport ini bisa diakses pada Mozilla Firefox atau Chrome. Dengan rekomendasi E-Raport ini maka diharapkan dapat menunjang serangkaian proses evaluasi pembelajaran yang lebih efektif dan efisien dengan memanfaatkan kecanggihan teknologi.
Seperti yang kita tahu penilaian merupakan unsur terpenting dari proses pembelajaran. Dari hasil penilaian itulah kita akan mengetahui kemampuan dari peserta didik. Pandemic covid 19 memaksa kita untuk melakukan kegiatan di rumah termasuk sekolah. Kebijakan penerapan sekolah jarak jauh (daring) membuat sebagian besar guru tidak bisa melihat secara langsung masing-masing kemampuan dari peserta didiknya. Akibatnya seluruh proses penilaian dilakukan secara online. Dengan adanya pembelajaran jarak jauh ini akan membuat peserta didik lebih individualis karena mereka sudah lama tidak bertemu dengan teman-temannya dan tidak berinteraksi dengan teman-temannya.

Untuk itu alternative pelaksanaan penilaian pasca pandemic yang lain yaitu dengan cara guru membuat kelompok yang terdiri dari 6-7 siswa. Tujuan dari adanya pembentukan kelompok ini yaitu agar peserta didik lebih mengenal dan berinteraksi dengan teman-temannya sehingga dengan adanya interaksi tersebut akan membuat sebuah kelompok semakin kuat. Selain itu tujuan lain dari penilaian kelompok ini agar karakter peserta didik lebih terbentuk lagi.

Selain itu di usia-usia jenjang SD peserta didik butuh lebih banyak interaksi dengan satu sama lain karena itu termasuk 
bagian dari proses perkembangan pribadi mereka di lingkungan sekolah. Jadi disini guru juga bisa memanfaatkan peluang untuk melakukan penilaian kepada peserta didiknya dilihat dari cara peserta didik berinteraksi dengan yang lainnya. Pada nantinya juga guru akan menugaskan peserta didik untuk membuat suatu karya secara berkelompok seperti menggambar dan mewarnai dilakukan secara berkelompok.

Hasil dari karya mereka nantinya akan di tempel di dinding kelas sebagai bentuk apresiasi kerja mereka secara kelompok. Dengan apresiasi yang diberikan tersebut akan lebih memotivasi peserta didik agar lebih belajar dengan giat lagi. Untuk teknik penilaiannya yaitu guru akan memberikan penilaian secara kelompok. Jika hasil dan proses dari karya tersebut memuaskan maka guru akan memberikan nilai yang memuaskan. Dari nilai yang sudah diberikan tersebut ditujukan untuk seluruh anggota kelompok. Sehingga tidak ada perbedaan nilai dari anggota satu dengan yang lain.

\section{KESIMPULAN}

Evaluasi merupakan hal yang terpenting dalam pembelajaran dimana evaluasi dapat memberikan sebuah informasi mengenai kemampuan dari peserta didik yang dapat diamati dengan indikator pembelajaran yang telah ditentukan oleh peserta didik sebelumnya. Selain dari itu setelah melewati masa pandemi, ada berbagai macam kegiatan terutama di bidang evaluasi yang mengalami perubahan. Oleh karena itu dengan adanya perubahan tersebut maka akan dapat menghasilkan sebuah alternatif baru untuk mengevaluasi peserta didik dengan menggabungkan model evaluasi peserta didik selama daring dan luring.

Maka dari itu, untuk menunjang keoptimalan pembelajaran diharapkan institusi dapat menerapkan beberapa rekomendasi penilain yang telah dibahas sebelumnya. Dengan menerapkan beberapa alternatif tersebut akan dapat memberikan dampak positif bagi peserta didik pada tiap aspek pendidikan seperti pengetahuan, keterampilan, karakter dan lain sebagainya

\section{DAFTAR PUSTAKA}

Afrilia Dwi., 2019. Strategi Guru Dalam Melaksanakan Penilaian

Pembelajaran Pada Masa Pandemic Covid 19 di Kelas Tinggi Sekolah Dasar. Universitas Negeri Medan

Akhmad Sudrajat. 2008. Pengertian Pendekatan, Strategi, Metode, Teknik dan Model Pembelajaran. Bandung : Sinar Baru Algensindo 
Alwasilah, et al. (1996). Glossary of educational Assessment Term. Jakarta: Ministry of Education and Culture Anonymous., 2019. Evaluasi Pembelajaran di SD. Universitas Negeri Semarang

Arikunto, S. dan Jabar. 2004. Evaluasi Program Pendidikan. Jakarta: Bumi Aksara

Indonesia, Peraturan Pemerintah Republik Indonesia Nomor 19 tahun 2005 tentang Standar Nasional pendidikan, Jakarta: Departemen Pendidikan Nasional, 2005
Helmawati. 2019. Pembelajaran dan Penilaian Berbasis HOTS. Bandung. PT:Remaja Rosdakarya Mahmudah, M., Kapi, M. B., \& Muslimah, M. (2021). Parental Participation-Based Portfolio Assessment during Covid-19 Pandemic. Bulletin of Science Education. 1 (1): 1-6.

Sudjana, Nana. 1995. Penilaian Hasil Proses Belajar Mengajar. Bandung. PT:Remaja Rosdakarya 